\title{
Denervated Schwann Cells Attract Macrophages by Secretion of Leukemia Inhibitory Factor (LIF) and Monocyte Chemoattractant Protein-1 in a Process Regulated by Interleukin-6 and LIF
}

\author{
George K. Tofaris, ${ }^{1}$ Paul H. Patterson, ${ }^{2}$ Kristjan R. Jessen, ${ }^{3}$ and Rhona Mirsky ${ }^{3}$ \\ ${ }^{1}$ Cambridge Centre for Brain Repair and Department of Neurology, University of Cambridge, Cambridge CB2 2PY, United \\ Kingdom, ${ }^{2}$ Division of Biology, California Institute of Technology, Pasadena, California 91125, and ${ }^{3}$ Department of \\ Anatomy and Developmental Biology, University College London, London WC1E 6BT, United Kingdom
}

Injury to peripheral nerves results in the infiltration of immune cells, which remove axonal- and myelin-derived material. Schwann cells could play a key role in this process by regulating macrophage infiltration. We show here that medium conditioned by primary denervated Schwann cells or the Schwannoma cell line RN22 produces chemotactic activity for macrophages. The presence of blocking antibodies to macrophage chemoattractant protein-1 (MCP-1) or leukemia inhibitory factor (LIF) reduced this activity to $\sim 35$ and $65 \%$ of control levels, respectively, and only $15 \%$ remained in the presence of both antibodies. The presence of chemotactic LIF in Schwann cell-conditioned medium was confirmed by using cells from lif-/- mice. Although interleukin-6 (IL-6) is not itself a chemotactic factor, we found that medium from il-6-/- nerves showed only $40 \%$ of the activity secreted by wild-type nerves. Furthermore, IL-6 rapidly induced LIF mRNA in primary Schwann cells, and LIF rapidly induced MCP-1 mRNA expression. Treatment of RN22 Schwannoma cells with IL-6 or LIF enhanced the secretion of the chemotactic activity of these cells.

These observations show that Schwann cells attract macrophages by secreting MCP-1 and LIF. They also provide evidence for an autocrine-signaling cascade involving IL-6, LIF, and MCP-1, which amplifies the Schwann cell-derived chemotactic signals gradually, in agreement with the delayed entry of macrophages to injured nerves.

Key words: chemotaxis; macrophage; leukemia inhibitory factor; interleukin 6; regeneration; neuropathy
Injury to peripheral nerve initiates a complex cascade of signals involving neurons, glia, and cells of the immune system that leads to Wallerian degeneration (for review, see Scherer and Salzer, 2001). An important component of this process is the invasion of macrophages. For many years, there have been uncertainties regarding the role of Schwann cells in regulating this macrophage recruitment (Beuche and Friede, 1984; Scheidt and Friede, 1987; Stoll et al., 1989). Two features of the myelomonocytic response in damaged peripheral nerves distinguish it from that seen in non-neuronal tissues (Perry and Brown, 1992): (1) after cut or crush injury, only small numbers of neutrophils are found in the distal segment, and (2) there is a delay of 2 or $3 \mathrm{~d}$ before a major influx of macrophages (Ramon y Cajal, 1928; Beuche and Friede, 1984; Crang and Blakemore, 1986; Perry et al., 1987; Stoll et al., 1989). This delay is consistent with the idea that the signals that most effectively attract macrophages are generated by a relatively slow-moving signaling cascade. This cascade is probably triggered by factors arising in proliferating dedifferentiating Schwann cells, as highlighted by observations on C57BL/Ola mice. Nerve injury in these mice does not induce acute Schwann cell dedifferentia-

\footnotetext{
Received Dec. 26, 2001; revised May 6, 2002; accepted May 24, 2002.

This work was supported by awards to G.K.T. from the Wolfson Foundation, the Howard Hughes Medical Institute through a California Institute of Technology (Caltech) Summer Undergraduate Research Fellowship, SmithKline Beecham Pharmaceuticals, and Trinity College (Cambridge, UK). R.M. and K.R.J. are supported by the Wellcome Trust. The work at Caltech was supported by a grant to P.H.P. from the National Institute of Neurological Disorders and Stroke. We thank Soheila Sharghi Namini and Sarah Dickinson for technical assistance with conditioned medium preparation and Doreen McDowell and Debbie Bartram for administrative assistance.

Correspondence should be addressed to George K. Tofaris, Cambridge Centre for Brain Repair and Department of Neurology, University of Cambridge, Robinson Way, Cambridge CB2 2PY, UK. E-mail: gt223@cam.ac.uk.

Copyright (C) 2002 Society for Neuroscience $\quad 0270-6474 / 02 / 226696-08 \$ 15.00 / 0$
}

tion and myelin breakdown, and macrophage invasion is sparse and slow (Lunn et al., 1989; Perry et al., 1990; Glass et al., 1993; Mack et al., 2001). This is attributable to protection offered by a chimeric gene containing an N-terminal fragment of ubiquitination factor E4B fused to nicotinamide mononucleotide adenyltransferase (Mack et al., 2001).

Cytokines induced in Schwann cells after peripheral nerve injury could play a key role in the interactions between Schwann cells and macrophages. The neuropoietic cytokines leukemia inhibitory factor (LIF) and interleukin-6 (IL-6) are both involved in the neuronal and immune responses to injury (Patterson, 1994; Gadient and Patterson, 1999). Schwann cells in transected nerves upregulate expression of LIF and IL-6 (Banner and Patterson, 1994; Curtis et al., 1994; Bolin et al., 1995; Bourde et al., 1996; Kurek et al., 1996). Moreover, LIF (but not IL-6) induces chemotaxis of peritoneal macrophages, and macrophage infiltration into injured sciatic nerve is delayed in LIF knock-out mice (Sugiura et al., 2000). Another potential Schwann cell-derived macrophage attractant, monocyte chemoattractant protein-1 (MCP-1), attracts macrophages in other systems and is induced in Schwann cells by nerve transection with a time course that lags behind that of LIF and IL-6 (Murphy, 1994; Baggiolini, 1998; Toews et al., 1998; Siebert et al., 2000). Schwann cells also produce a number of other cytokines, including IL- $1 \beta$, tumor necrosis factor- $\alpha$ (TNF- $\alpha$ ), and IL-8 (Bergsteinsdottir et al., 1991; Wagner and Myers, 1996; Rutkowski et al., 1999).

Thus, although Schwann cells deprived of axonal contact in transected nerves express several signals that might act on macrophages, it has not been shown directly that these Schwann cells produce macrophage chemotactic activity. Moreover, although there are many studies on cytokine induction after peripheral 
nerve injury, little is known about the mechanisms that regulate their expression. A recent paper pinpoints $\mathrm{TNF}-\alpha$ as an inducer of MCP-1 in Schwann cells after nerve injury, particularly at the relatively late time of $4 \mathrm{~d}$ (Subang and Richardson, 2001). Here, we have examined signals that might contribute to Schwann cell-derived chemotactic activity at earlier time points and studied how their expression is regulated. We have directly measured macrophage chemotactic activity generated by normal Schwann cells, RN22 Schwannoma cells, and cut nerves taken from LIF and IL-6 knock-out animals. We find that LIF and MCP-1 are important components of the secreted signals that attract macrophages. We also provide evidence for an autocrine-signaling cascade involving IL-6, LIF, and MCP-1 in Schwann cells that could result in a gradual amplification of the macrophage attracting activity secreted by these cells.

\section{MATERIALS AND METHODS}

Defined medium. For all conditioned media, we used a supplemented defined medium identical to that used in previous studies (Jessen et al., 1994). It consists of a 1:1 mixture of DMEM and Ham's F-12 supplemented with insulin $(5 \mu \mathrm{g} / \mathrm{ml})$, transferrin $(100 \mu \mathrm{g} / \mathrm{ml})$, glutamine $(1$ $\mathrm{mM})$, progesterone $(60 \mathrm{ng} / \mathrm{ml})$, putrescine $(16 \mu \mathrm{g} / \mathrm{ml})$, selenium $(160$ $\mathrm{ng} / \mathrm{ml}), \mathrm{T} 4(400 \mathrm{ng} / \mathrm{ml}), \mathrm{T} 3(10.1 \mathrm{ng} / \mathrm{ml})$, bovine serum albumin (BSA) $(0.035 \%)$, penicillin $(100 \mathrm{IU} / \mathrm{ml})$, and streptomycin $(100 \mathrm{IU} / \mathrm{ml})$. For all conditioned media, $20 \mu \mathrm{M}$ leupeptin was added to the defined medium to prevent proteolysis. Sources of the reagents used have been detailed in previous papers (Jessen et al., 1994; Meier et al., 1999).

Schwann cell cultures and conditioned medium preparation. Sciatic nerves from 4-d-old rats were dissociated, and Schwann cells were purified by immunopanning to remove contaminating cells, essentially as described previously (Jessen et al., 1990, 1994; Lee et al., 1997). Schwann cells were resuspended in defined medium, counted, and plated onto laminin-coated coverslips for immunostaining with anti-S100 antibodies as described previously (Meier et al., 1999). This confirmed that Schwann cells are $99.5 \pm 0.5 \%$ pure after immunopanning. For conditioned medium preparation, Schwann cells were plated onto 35 -mm-diameter poly-L-lysine and laminin-coated tissue culture plastic dishes $\left(4.5-7 \times 10^{5}\right.$ cells total $)$. After $24 \mathrm{hr}$ of incubation, the conditioned medium was collected, centrifuged for $10 \mathrm{~min}$ at $1000 \mathrm{rpm}$, and stored in BSA $(3 \mathrm{mg} / \mathrm{ml})$-coated cryotubes at $-80^{\circ} \mathrm{C}$ until further use. For LIF- or IL-6-treated primary Schwann cells, recombinant mouse LIF or recombinant rat IL-6 (R \& D Systems, Oxon, UK) was added to the cultures at two different concentrations, 2 and $20 \mathrm{ng} / \mathrm{ml}$, always accompanied by a control with no treatment. Cells were incubated under standard conditions $\left(37^{\circ} \mathrm{C}, 5 \% \mathrm{CO}_{2}\right)$ for 1 and $3 \mathrm{hr}$ (LIF) and for 1, 3, 6, 10.5, and $24 \mathrm{hr}$ (IL-6).

RN22 Schwannoma cell-conditioned medium. Cells were grown in Roswell Park Memorial Institute (RPMI)-1640 (Sigma-Aldrich, Poole, UK) containing $10 \%$ fetal calf serum (Sigma-Aldrich) until they reached $70 \%$ confluence. Subsequently, they were changed to defined medium and left for $24 \mathrm{hr}$ to adapt to the new conditions. Fresh medium was then added, and the cell line was treated with $20 \mathrm{ng} / \mathrm{ml} \mathrm{LIF}$ or IL-6. After a $3 \mathrm{hr}$ incubation in $37^{\circ} \mathrm{C} / 5 \% \mathrm{CO}_{2}$, the cells were washed three times, and fresh defined medium was added. After an additional $24 \mathrm{hr}$ incubation, the conditioned medium was removed, centrifuged for $10 \mathrm{~min}$ at 1000 $\mathrm{rpm}$, and stored at $-80^{\circ} \mathrm{C}$ until further use.

Mouse sciatic nerve conditioned medium. The strain of LIF knock-out (lif-/-) mice used in this work was that of Stewart et al. (1992), which has been intermittently back-crossed with C57BL/6 to maintain fertility and viability. The IL-6 knock-out strain (il-6-/-) was produced by Kopf et al. (1994) and was purchased from The Jackson Laboratory (Bar Harbor, MA.) Sciatic nerves were excised from wild-type, lif-/-, il$6-/-$, as well as LIF/IL-6 double knock-out (lif/lil-6-/-) mice. The nerves were cleaned of debris, cut in $2 \mathrm{~mm}$ pieces, and cultured in 24 well plates for 24 and $48 \mathrm{hr}$. The supernatant was aliquoted for storage as described above.

Peritoneal macrophages and chemotaxis assay. BALB/c mice between 8 and 10 weeks of age were injected intraperitoneally with $2 \mathrm{ml}$ of $10 \%$ protease peptone (Difco, Detroit, MI). Four days later, peritoneal exudate cells were collected by lavage of the peritoneal cavity with $5 \mathrm{ml}$ of ice-cold PBS. After washing with PBS, the peritoneal cells were resuspended at a concentration of $10^{6} / \mathrm{ml}$ in RPMI-1640 containing $0.1 \%$ BSA. Chemotactic activity was assayed in a multiwell microchamber
AP48 (Neuroprobe, Gaithersburg, MD) (Falk et al., 1980) after optimal chemotaxis conditions were established (Sugiura et al., 2000). This method of measuring chemotaxis is now widely used and is thought to minimize complications associated with earlier assays (Wilkinson, 1982; Bignold, 1988). Briefly, $25 \mu \mathrm{l}$ of chemoattractant was added to the bottom wells. A polycarbonate filter sheet $(25 \times 80 \mathrm{~mm}, 8 \mu \mathrm{m}$ pores; Nucleopore Corp., Pleasanton, CA), without polyvinylpyrrolidone coating to prevent migrated cells from falling off (Harvath et al., 1980), was placed on top of the wells in the bottom plate. The gasket and top plate were fixed in place, and the upper wells were carefully loaded with $50 \mu \mathrm{l}$ of cell suspension $\left(5 \times 10^{4}\right.$ cells $)$. The assembly was incubated for $100 \mathrm{~min}$ at $37^{\circ} \mathrm{C}$ with $5 \% \mathrm{CO}_{2}$ in humidified air. After incubation, the top plate, gasket, and filter were removed; cells on the top of the filter that had not migrated through were wiped off; and the filter was fixed and stained with Hema color (Harleco, Gibbstown, NJ). All cells that had migrated were counted under light microscopy at $400 \times$ magnification. Data are presented as the chemotactic index, which is defined as the number of cells that migrated in the presence of a test protein or conditioned medium divided by the number of cells that migrated in the presence of medium alone (Sugiura et al., 2000). In each experiment, the efficiency of migration was monitored using recombinant MCP-1 as a positive control. Experiments in which the chemotactic index obtained with MCP-1 at 10 $\mathrm{ng} / \mathrm{ml}$ was $<3$ were discarded.

Antibody blocking. Anti-LIF and anti-MCP-1 antibodies (R \& D Systems) were used at a concentration of $50 \mu \mathrm{g} / \mathrm{ml}$. In control experiments, we confirmed that antibodies to MCP-1 block the activity of murine MCP-1. We also confirmed the specificity of the blocking experiments by showing that blocking antibodies for neurotrophin-3 (NT-3) $(2.5 \mu \mathrm{g} / \mathrm{ml})$, a factor that is secreted into Schwann cell-conditioned medium (Meier et al., 1999), or hepatocyte growth factor $(5 \mu \mathrm{g} / \mathrm{ml})$, a known chemoattractant (Galimi et al., 2001), do not inhibit the chemotactic activity.

Isolation of RNA and first-strand cDNA synthesis. Total RNA was prepared using Ultraspec reagent (Biotecx, Houston, TX) or TRIzol reagent (Invitrogen, Carlsbad, CA), according to the manufacturers' instructions. Total RNA from immunopanned Schwann cells and from intact nerves was quantified by measuring the optical density at 260 and $280 \mathrm{~nm}$ and analyzed for integrity by agarose gel electrophoresis under denaturing conditions.

Semiquantitative reverse transcriptase-PCR. One microgram (LIFtreated Schwann cell cultures), $2 \mu \mathrm{g}$ (intact nerve, Schwann cell cultures, and IL-6-treated Schwann cell cultures) total RNA was reversetranscribed into cDNA in a $50 \mu \mathrm{l}$ reaction containing $50 \mathrm{~mm}$ Tris- $\mathrm{HCl}$, $\mathrm{pH} 8.3,75 \mathrm{~mm} \mathrm{MgCl}_{2}, 10 \mathrm{~mm}$ DTT, 0.5-1.5 mm deoxyNTPs (dNTPs), and either $100-300 \mathrm{ng}$ of random hexamers or $500 \mathrm{ng}$ of oligo-dT $\mathrm{d}_{17-18}$ as primer and 200-300 U of Superscript II reverse transcriptase (RT) (Invitrogen). The reaction was incubated for $90 \mathrm{~min}$ at $42^{\circ} \mathrm{C}$, followed by 10 min at $70^{\circ} \mathrm{C}$. The remaining RNA was denatured by adding $1 \mu \mathrm{l}$ of RNase A (10 mg/ml; Boehringer Mannheim, East Sussex, UK) and incubating for $30 \mathrm{~min}$ at $37^{\circ} \mathrm{C}$. The relative amount of cDNA synthesized from each sample was determined by PCR amplification using specific primers for $18 \mathrm{~S}$ or glyceraldehyde-3-phosphate dehydrogenase (GAPDH). The primer pairs were designed as follows (product size in parentheses): MCP-1 forward primer, 5'-ctgggectgttgttcacagttgc-3'; MCP-1 reverse primer, 5'gttggtggagttcgtgaagacatc-3' (380 bp) (Sun et al., 1997); macrophage inhibitory protein-1 $\alpha$ (MIP-1 $\alpha$ ) forward primer, $5^{\prime}$-gaaggtctccaccactgccettgc-3'; MIP-1 $\alpha$ reverse primer, $5^{\prime}$-gactcgaccttgacttacggact-3' (350 bp) (Sun et al., 1997); LIF forward primer, $5^{\prime}$-ccgtgtcacggcaacctcatgaaccagatc-3'; LIF reverse primer, 5'-ggggacacagggcacatccacatggcccac-3' (395 bp) (Patterson and Fann, 1992); inducible nitric oxide synthase (iNOS) forward primer, 5'-tgatgtgctgcctctggtct-3'; iNOS reverse primer, 5'-acttcctccaggatgttgta-3' (350 bp) (Bonmann et al., 1997); 18S forward primer, 5' -cctcgaaagagtcctgta-3'; 18 S reverse primer, 5' -gggaacgcgtgcatttat-3' (350 bp) (Blanchard et al., 1996); GAPDH forward primer, $5^{\prime}$-ttccagtatgactctaccc-3'; and GAPDH reverse primer, 5'-atggactgtggtcatgagccc-3' (398 bp) (Brown et al., 1997). One microliter of cDNA from each sample was amplified in a $50 \mu \mathrm{l} \mathrm{PCR}$, containing $1 \times$ reaction buffer $(10 \mathrm{~mm}$ Tris- $\mathrm{HCl}, \mathrm{pH} 9.0,50 \mathrm{~mm} \mathrm{KCl}$, and $0.1 \%$ Triton X-100); 1-2 mM $\mathrm{MgCl}_{2}, 0.2 \mathrm{~mm}$ dATP, dGTP, dTTP, and dCTP; a $0.5 \mathrm{~mm}$ concentration of each primer listed above; and $1.5 \mathrm{U}$ of Taq DNA polymerase (Invitrogen). The cDNA was amplified after determining the optimal number of cycles and annealing temperature for each primer: 18S, 21 cycles; MCP-1, 25 cycles when oligo-dT 17-18 $_{\text {primers were }}$ used or 35 cycles when random hexamers were used for reverse transcription; MIP- $1 \alpha$ and iNOS, 35 cycles; and LIF, 35 cycles. For MCP-1 and MIP-1 $\alpha$, PCRs were performed under a hot start program $\left(94^{\circ} \mathrm{C}\right.$ for 4.5 
min). Cycling conditions were as follows: the mixture was initially incubated once for 3 or $5 \mathrm{~min}$ at $94^{\circ} \mathrm{C}$; denatured at $94^{\circ} \mathrm{C}$ for $30 \mathrm{sec}$ or $1 \mathrm{~min}$; and annealed at $50^{\circ} \mathrm{C}(\mathrm{MCP}-1), 55^{\circ} \mathrm{C}(18 \mathrm{~S}), 57^{\circ} \mathrm{C}(\mathrm{LIF}$ and GAPDH), or $60^{\circ} \mathrm{C}$ (iNOS and MIP-1 $\alpha$ ) for $1 \mathrm{~min}$, followed by $72^{\circ} \mathrm{C}$ for $30 \mathrm{sec}$ or $1 \mathrm{~min}$ with an extension of $5 \mathrm{~min}$. The number of cycles used for semiquantitative PCR was in the linear part of the amplification profile.

Relative quantification of RT-PCR products. The intensity of the PCR products was measured using densitometry (Scion Image 1.62c software; Scion Corp., Frederick, MD), and the ratio of the intensity of MCP-1 and LIF signal to $18 \mathrm{~S}$ and/or GAPDH was calculated for each sample. These ratios were compared at the indicated time points to obtain a numerical estimate of the changes in the cDNA of interest after treatment with either IL-6 or LIF.

Statistical analysis. All results are presented as mean \pm SEM. The statistical significance of differences in macrophage migration toward putative stimuli versus medium controls was analyzed by Student's $t$ test. All experiments were performed three times, four replicates each, unless otherwise stated.

\section{RESULTS}

\section{Primary Schwann cells secrete chemotactic activity}

Although in situ hybridization and other studies of transected nerves show that injury induces cytokine and chemokine mRNAs in Schwann cells (see the introductory remarks), it has not been shown directly that Schwann cells secrete macrophage chemotactic activity. To test this, we used cultures of primary Schwann cells as a model of denervated Schwann cells in the distal stump of cut nerves. This is because there is little evidence for a major qualitative difference in molecular expression between Schwann cells in distal nerve stumps and Schwann cells cultured in vitro in the absence of neurons, with the possible exception of nerve growth factor (Mirsky and Jessen, 1990). For comparison, we also used segments cut from mouse sciatic nerves placed in culture without dissociation and the Schwannoma cell line RN22. If Schwann cells secrete chemotactic signals, medium conditioned by these tissues should induce macrophage chemotaxis. We tested this using the AP48 microchamber assay. We found that defined medium conditioned for $24 \mathrm{hr}$ by dense cultures of immunopanned Schwann cells from nerves of 4-d-old rats, nerve segments, or the RN22 cell line all contained significant chemotactic activity (Fig. 1A). The chemotactic index for all three media was similar when compared with the migration stimulated by the well established macrophage attractant MCP-1 (10 ng/ml) in parallel experiments on sister cultures. The Schwann cell-conditioned medium was shown to act in a dose-dependent manner (Fig. 1B).

\section{MCP-1 and LIF are components of the Schwann cell- derived chemotactic activity}

Concerning the identity of the Schwann cell-derived chemotactic signals, we initially considered MCP-1, in view of its potent chemotactic and activating properties in macrophage migration assays and in view of other evidence that MCP-1 is a component of the regulatory cascades that attract macrophages into cut nerves in vivo (Toews et al., 1998; Siebert et al., 2000; Subang and Richardson, 2001). First, we tested whether MCP-1 is upregulated when Schwann cells are removed from axonal contact and cultured under conditions used to generate the conditioned medium. RT-PCR was used to compare mRNA from freshly isolated intact nerves representing Schwann cells in normal contact with axons both with mRNA from immunopurified Schwann cells after a $24 \mathrm{hr}$ period in vitro and with mRNA from unpurified cultures of dissociated nerve containing both Schwann cells and fibroblasts isolated after a $24 \mathrm{hr}$ period in vitro. In addition to MCP-1 mRNA, we also examined mRNA for the related $\beta$-chemokine MIP-1 $\alpha$ and for iNOS, an enzyme upregulated in Schwann cells

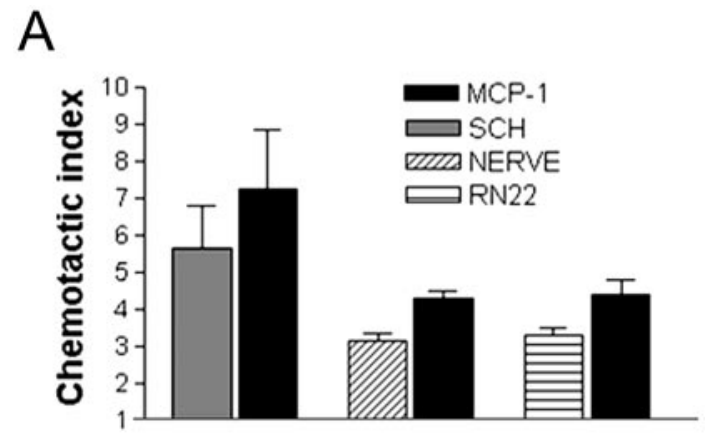

B

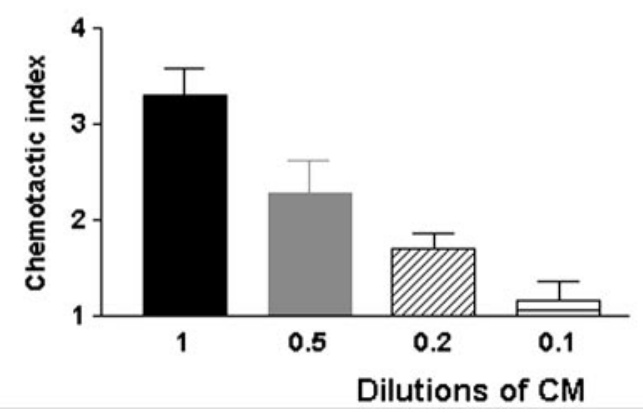

Figure 1. Schwann cells secrete macrophage chemoattractant activity. $A$, Immunopurified cells $(S C H)$, a Schwann cell line (RN22), and nerve segments (NERVE) secrete macrophage chemoattractant activity. All media were conditioned for $24 \mathrm{hr}$ and used undiluted (see Materials and Methods). For each of these three determinations, MCP-1 $(10 \mathrm{ng} / \mathrm{ml})$ served as a positive control in a parallel assay as shown. Defined medium served as negative control. In this and all subsequent illustrations of migration assays, the results are expressed as chemotactic index (see Materials and Methods). $B$, The Schwann cell-derived macrophage chemotactic activity acts in a dose-dependent manner. Conditioned medium $(C M)$ from immunopurified Schwann cells was used undiluted and at the dilutions indicated.

in response to treatment with the inflammatory cytokines interferon- $\gamma$ or TNF- $\alpha$ (Gold et al., 1996). This comparison showed that whereas intact nerves expressed undetectable levels of these molecules, purified primary Schwann cells selectively upregulated MCP-1. In contrast, mixed cultures containing both Schwann cells and fibroblasts expressed all signals tested (i.e., MCP-1, MIP-1 $\alpha$, and iNOS) (Fig. 2).

Therefore, we tested whether the chemotactic activity present in medium conditioned by purified Schwann cells could be inhibited by antibodies that selectively neutralize MCP-1. We extended these experiments to include antibodies that neutralize LIF, because this cytokine is induced in Schwann cells by sciatic nerve injury in vivo and also has macrophage chemotactic activity in vitro (Banner and Patterson, 1994; Sugiura et al., 2000). We found that neutralizing antibodies against either MCP-1 or LIF could inhibit the chemotactic activity in the conditioned medium (Fig. $3 A$ ). The MCP-1 antibody blocked $60-70 \%$ of the activity $(p<0.0001)$, whereas the anti-LIF antibody blocked $30-40 \%$ of the activity $(p<0.006)$. When the conditioned medium was incubated with both antibodies, only $15 \%$ of the chemotactic activity remained $(p<0.0001)$. We have shown previously that the RN22 Schwann cell line, like Schwann cells, secreted a macrophage chemoattractant (Fig. $1 A$ ). Supporting a major role for 


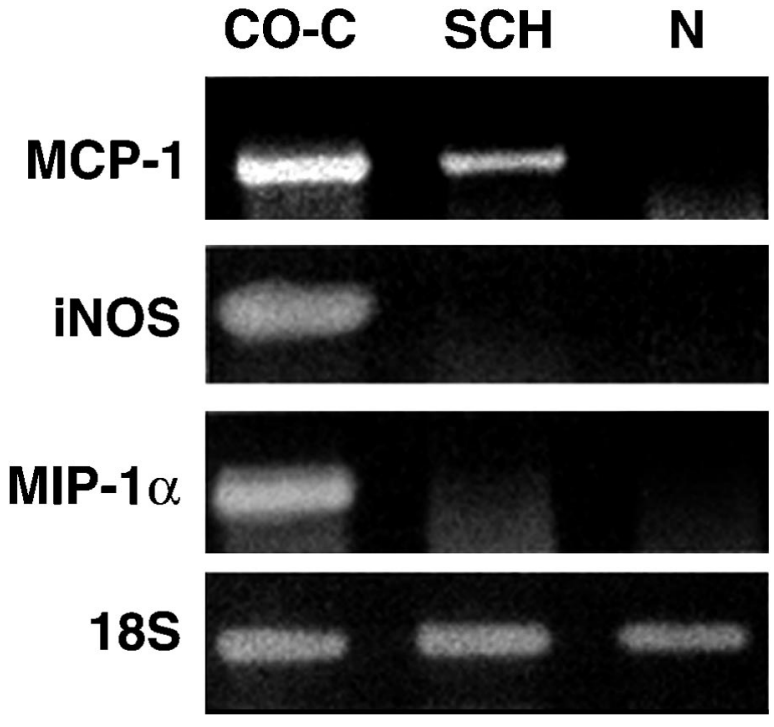

Figure 2. Schwann cells upregulate MCP-1 mRNA when deprived of axonal contact. mRNA levels in freshly isolated nerves $(N)$ are compared with levels in unpurified cultures of dissociated nerve $(\mathrm{CO}-\mathrm{C})$ and purified Schwann cells $(\mathrm{SCH})$ after overnight incubation. RT-PCR results are shown for MCP-1-, iNOS-, MIP-1 $\alpha$-, and 18S-specific primers. $18 \mathrm{~S}$ control samples were used to demonstrate equal loading in all tracks. These results show that purified Schwann cells upregulate MCP- 1 mRNA but not MIP- $1 \alpha$ or iNOS mRNA when they are deprived of axonal contact in vitro, whereas mixed cultures (containing Schwann cells and fibroblasts) also upregulate iNOS and MIP- $1 \alpha$.

MCP-1 as a glial cell-derived chemotactic signal, we found that neutralizing MCP-1 antibodies also blocked $\sim 60 \%$ of the RN22derived activity (Fig. 3B).

If LIF acts as a Schwann cell-derived chemoattractant, conditioned medium from nerves of mice in which LIF has been genetically inactivated should be relatively ineffective in attracting macrophages. We tested this by comparing macrophage chemotactic activity in media conditioned by nerve segments from wild-type or lif-/- mice (Fig. $4 A$ ). We found that medium from lif- - - nerves contained only $40 \%$ of the activity found in media from wild-type nerves $(p<0.013)$, in agreement with the experiments above using blocking antibodies.

Together, these experiments strongly indicate that MCP-1 and LIF are the principal factors for macrophage chemotactic activity directly secreted by Schwann cells.

\section{Autocrine circuits involving IL-6 and LIF regulate the secretion of chemotactic activity from Schwann cells}

We then considered how the secretion of chemotactic agents such as MCP-1 and LIF might be regulated. After axotomy in vivo, LIF mRNA levels peak at $24 \mathrm{hr}$, whereas mRNA for the major macrophage attractant MCP-1 does not reach peak levels until 48 hr after cutting (Banner and Patterson, 1994; Carroll and Frohnert, 1998; Toews et al., 1998; Subang and Richardson, 2001). The relatively slow time course of MCP-1 induction suggests the existence of earlier regulatory cascades triggered by nerve transection. A number of factors point to IL-6 as a favorable candidate for such a role: (1) IL- 6 mRNA is rapidly induced by axotomy, reaching a peak at $12 \mathrm{hr}$ (Bolin et al., 1995; Bourde et al., 1996; Kurek et al., 1996), (2) IL-6 has been implicated previously in neuronal and immune responses to injury (Gadient and Patterson, 1999), and (3) although IL-6 does not itself attract macrophages (Sugiura et al., 2000), cut nerves in il-6-/- mice
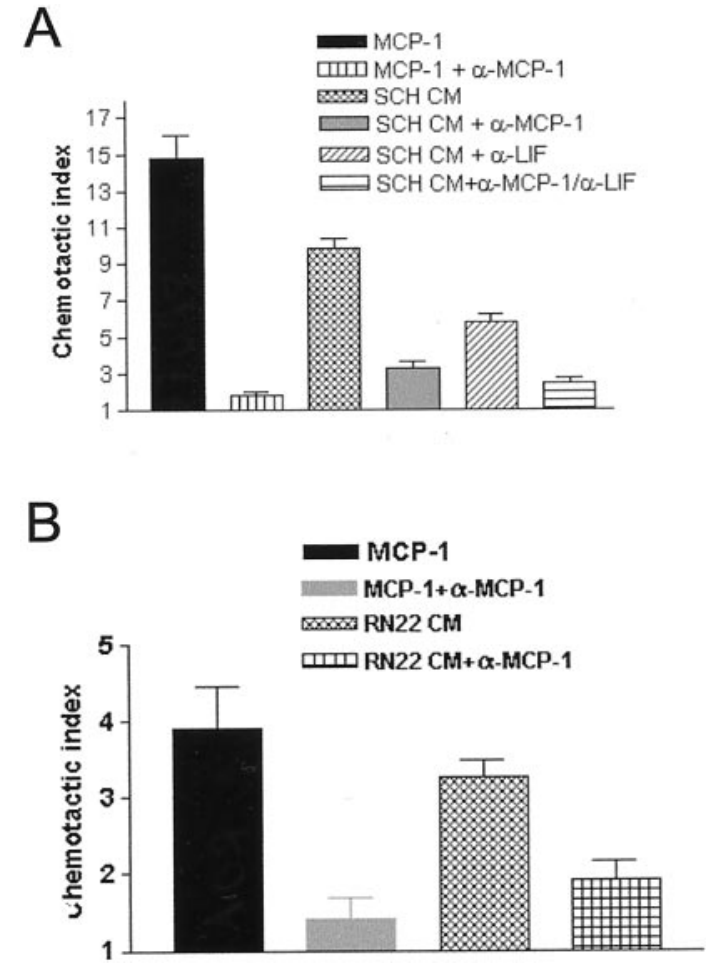

Figure 3. Schwann cells secrete chemotactic activity that is blocked by anti-MCP-1 and/or anti-LIF antibodies. $A$, Conditioned medium $(C M)$ from primary rat Schwann cells $(\mathrm{SCH})$ contains chemotactic activity that can be blocked by anti-MCP-1 $(\alpha-M C P-1)$ and/or anti-LIF $(\alpha-L I F)$ neutralizing antibodies. The MCP-1 antibody blocks $60-70 \%$ of this activity $(p<0.0001)$, whereas the LIF antibody blocks $30-40 \%$ of this activity $(p<0.006)$. When the conditioned medium is incubated with both antibodies, only $15 \%$ of the chemotactic activity remains $(p<0.0001) . B$, Neutralizing MCP-1 antibodies reduce chemotactic activity in medium conditioned by RN22 cells by $60 \%(p<0.002)$ in accordance with findings using conditioned medium from primary Schwann cells. $A, B$, MCP-1 was used as a positive control, and MCP-1 in combination with the anti-MCP-1 antibody was used to confirm the effectiveness of the blocking antibody.

show reduced macrophage recruitment (Klein et al., 1997), suggesting that IL-6 attracts macrophages to nerves through an indirect mechanism.

To test the involvement of IL-6, we compared the chemotactic activity of medium conditioned by nerves from il-6-/ - mice with conditioned medium from segments of wild-type nerves (Fig. $4 B)$. We found that, although IL-6 does not attract macrophages (above), the medium conditioned by $i l-6-/-$ cells contained only $40 \%$ of the activity present in medium from normal nerves $(p<$ 0.013 ), a figure similar to that obtained with medium from lif-/nerves (Fig. $4 A$ ). In these experiments, we also examined medium conditioned by nerves lacking both IL-6 and LIF. Although the medium from these lif/il-6-/- nerves showed a strong reduction in macrophage recruiting activity when compared with normal nerves $(p<0.0004)$, the difference between media from the double knock-out nerves and media from the corresponding single knock-out nerves was not statistically significant. This indicates that both LIF and IL-6 are essential for nerves to generate maximum chemotactic activity.

The low chemotactic activity in medium from il-6-/- nerves could be explained if the role of IL- 6 was to act as a positive regulator for the generation of downstream chemotactic factors. First we tested whether IL-6 regulated the expression of mRNAs for LIF in immunopurified Schwann cells using RT-PCR (Fig. 
A

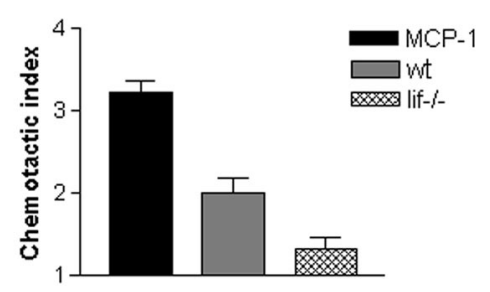

B

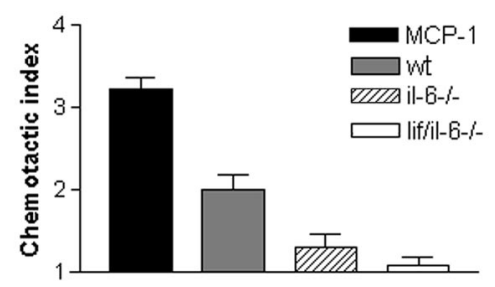

Figure 4. Conditioned medium from nerves of lif-/- mice and il-6-/mice shows less chemotactic activity than medium from normal wild-type nerves $(w t)$. $A$, Medium conditioned for $24 \mathrm{hr}$ by nerve segments from lif- $/-$ mice contains significantly less chemotactic activity than media conditioned by nerves from wild-type mice. $B$, Media conditioned for 24 hr by nerve segments from $i l-6-/-$ mice or by nerves from mice lacking both IL-6 and LIF (lif/il-6-/-) contain significantly less chemotactic activity than media from wild-type nerves. The difference between media from $i l-6-/-$ and lif/il-6-/- nerves is not statistically significant. $A, B$, MCP-1 (10 ng/ml) was used as a positive control.

$5 A$ ). We found that IL-6 strongly increased the abundance of LIF mRNA from $6 \mathrm{hr}$ onward (significant elevation was seen already at $1 \mathrm{hr}$; data not shown) (Fig. 5A). We then tested whether LIF, being rapidly and therefore presumably directly induced by IL-6, would, in turn, rapidly induce MCP-1. Using RT-PCR, we determined that already at 1 and $3 \mathrm{hr}$, exposure to LIF $(20 \mathrm{ng} / \mathrm{ml})$ clearly increased the levels of MCP-1 mRNA (Fig. 5B). Therefore, these results suggest the existence of a signaling cascade in which IL-6 induces LIF, which then induces MCP-1, a model that is consistent with the sequential activation of these genes in cut nerves (for references, see above) and our finding that medium conditioned by $i l-6-/-$ cells lacks chemotactic activity despite the fact that IL-6 is not a chemoattractant.

This idea was tested in two additional sets of experiments. First, it predicts that it might be possible to demonstrate induction of MCP-1 when IL-6 is added to Schwann cell cultures, although this effect might be small because it would depend on a sufficient concentration of LIF building up in the culture dish. Furthermore, because this effect should be indirect and mediated by LIF, the MCP-1 induction should take place with a delay when compared with the induction of LIF by IL-6. Therefore, we used RT-PCR to monitor MCP-1 mRNA in purified Schwann cell cultures after addition of IL-6 (Fig. 5C). Elevation of MCP-1 mRNA was observed, although a significant response was not seen until at the $10 \mathrm{hr}$ time point. This finding is in agreement with previous observations that IL-6 does not elevate MCP-1 mRNA in Schwann cells $3 \mathrm{hr}$ after application (Subang and Richardson, 2001).

Second, if the IL-6-stimulated LIF expression and the LIFstimulated MCP-1 expression shown above were functionally significant, cells exposed to either IL-6 or LIF should generate
A IL-6 addition

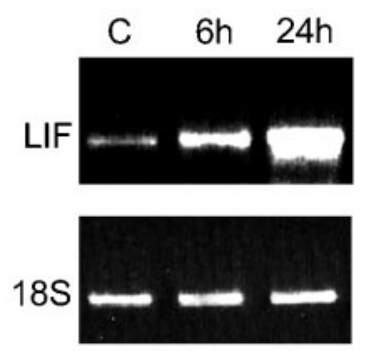

B LIF addition

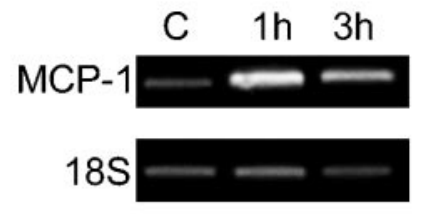

C IL-6 addition
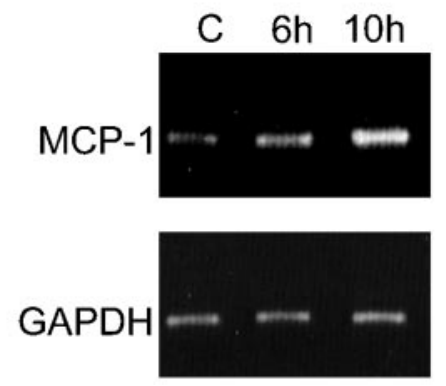

Figure 5. IL-6 enhances cytokine expression in Schwann cells. A, IL-6 enhances expression of LIF in purified Schwann cells. The results are from RT-PCR assays of untreated Schwann cells [controls $(C)$ ] and Schwann cells treated with $20 \mathrm{ng} / \mathrm{ml} \mathrm{IL-} 6$ for 6 and $24 \mathrm{hr}$ as indicated. Note that the elevation of LIF mRNA is already clear at $6 \mathrm{hr}$. $18 \mathrm{~S}$ control samples were run as shown to control for loading in all tracks. Densitometric comparison of the LIF signals with the corresponding $18 \mathrm{~S}$ signals shows that LIF elevation is threefold at $6 \mathrm{hr}$ and sevenfold at $24 \mathrm{hr}$ (see Materials and Methods). $B$, LIF enhances expression of MCP-1 in purified Schwann cells. The results show RT-PCR assays of untreated cells (C) and Schwann cells treated with $20 \mathrm{ng} / \mathrm{ml} \mathrm{LIF}$ for 1 and $3 \mathrm{hr}$ as indicated. Note that the elevation of MCP-1 mRNA is already clear at 1 hr. $18 \mathrm{~S}$ control samples were run as shown to control for loading in all tracks. Densitometric comparison of the LIF signals with the corresponding $18 \mathrm{~S}$ signals shows that MCP-1 elevation is fourfold at $1 \mathrm{hr}$ and fivefold at $3 \mathrm{hr}$. C, IL-6 enhances expression of MCP-1 in purified Schwann cells. The results show RT-PCR assays of untreated cells $(C)$ and cells treated with $20 \mathrm{ng} / \mathrm{ml}$ IL-6 for 6 and $10 \mathrm{hr}$ as indicated. The elevation of MCP-1 mRNA is not unambiguous until the $10 \mathrm{hr}$ point. This delay is consistent with the idea that IL- 6 controls MCP-1 levels indirectly by activating LIF (Fig. 7). GAPDH PCR was run as shown to control for loading in all tracks. Densitometric comparison of the LIF signals with the corresponding GAPDH signals shows that MCP-1 elevation is 1.4-fold at $6 \mathrm{hr}$ and threefold at $10 \mathrm{hr}$.

more chemotactic activity than unstimulated control cells. To test this possibility, the RN22 Schwann cell line was treated for $3 \mathrm{hr}$ with LIF or IL-6 (both at $20 \mathrm{ng} / \mathrm{ml}$ ). The cells were then washed extensively to ensure that any added factors were removed from the wells. Conditioned medium was collected from the cells after 


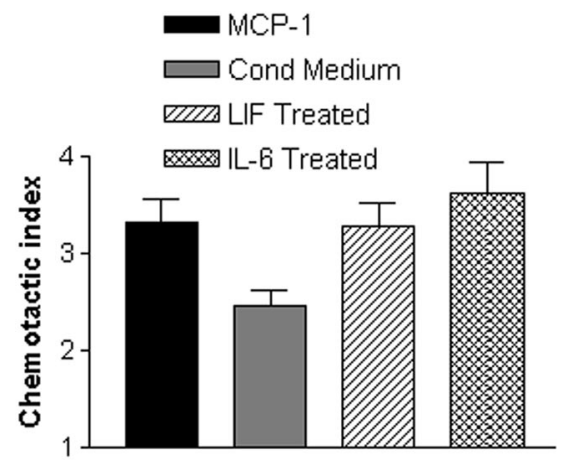

Figure 6. Exogenous LIF or IL-6 induces chemotactic activity in the RN22 Schwann cell line. RN22 cells were treated for $3 \mathrm{hr}$ with $20 \mathrm{ng} / \mathrm{ml}$ LIF or IL-6 and then washed extensively. Conditioned medium (Cond Medium) was collected from the cells after an additional $24 \mathrm{hr}$ incubation and tested in the migration assay. LIF and IL- 6 increased the level of chemotactic activity in conditioned medium by $34 \%(p<0.02)$ and $44 \%$ $(p<0.005)$, respectively.

an additional $24 \mathrm{hr}$ incubation in defined medium. We found that preincubation with either LIF or IL-6 increased macrophage chemotactic activity by $34 \%(p<0.02)$ and $44 \%(p<0.005)$, respectively (Fig. 6).

\section{DISCUSSION}

Together, the experiments reported here are consistent with the notions that: (1) Schwann cells directly attract macrophages by secretion of MCP-1 and LIF and (2) induction of these chemoattractants in denervated Schwann cells is regulated by autocrine circuits involving IL-6 and LIF (Fig. 7). The existence of such a signaling cascade and the consequent late elevation of the major macrophage attractant MCP-1 is in line with the delayed entry of macrophages into cut nerves in vivo (see the introductory remarks).

In a functional blocking assay, we show that both MCP-1 and LIF are present in Schwann cell-conditioned medium, and that they are the principal mediators of the Schwann cell-derived chemotactic activity. In our experiments, MCP-1 accounted for $60-70 \%$ of Schwann cell chemotactic activity, whereas LIF ac- counted for $30-40 \%$. In agreement with this, recombinant LIF has direct chemotactic activity on macrophages in the microchamber assay, with a maximum chemotaxis index that is onehalf that of recombinant MCP-1 (Sugiura et al., 2000). MCP-1 also accounted for $60 \%$ of the chemotactic activity secreted by RN22, a cell line that closely mimics primary Schwann cells in other aspects of injury and repair responses (Varon et al., 1981; Longo et al., 1982; Hill, 1987). The role of LIF in chemotaxis is also supported by two findings. The addition of LIF to primary Schwann cell cultures induced MCP-1 mRNA, whereas conditioned medium from lif- $/-$ mouse sciatic nerves contained significantly less chemotactic activity than wild-type controls. Our data are also consistent with in vivo evidence that macrophage recruitment to peripheral nerves is reduced in mice lacking the main receptor for $\mathrm{MCP}-1$ or in lif- $/-$ mice after sciatic nerve and/or brain injury (Siebert et al., 2000; Sugiura et al., 2000).

Because both LIF and IL-6 are known to induce cascades of inflammatory mediators in other cell types (Villiger et al., 1992; Hartner et al., 1997; Shimon et al., 1997; Marin et al., 2001), we investigated whether they could regulate Schwann cell chemotactic activity in a similar manner. IL-6 is not directly chemotactic for macrophages (Sugiura et al., 2000), but nerve injury in il-6-/mice results in reduced macrophage recruitment (Klein et al., 1997). Our finding that chemotactic activity secreted by cut nerves from il-6-/- mice is also reduced compared with controls suggests that this is the reason for the reduced influx of macrophages. Treatment of primary Schwann cells with IL-6 induces LIF at both early ( 1 and $3 \mathrm{hr}$ ) (our unpublished observations) and more prolonged time points. Furthermore, treatment of RN22 cells with either LIF or IL- 6 enhances the chemotactic activity secreted in the conditioned medium. When combined with evidence from others that IL- 6 does not directly induce MCP-1 in Schwann cells within 3 hr (Subang and Richardson, 2001), our data suggest that induction of MCP-1 in Schwann cells may be dependent on previous induction of LIF or other factors that can induce MCP-1 directly.

Therefore, Schwann cell-derived IL-6 and LIF could induce the expression of downstream chemotactic signals in Schwann cells themselves. After nerve transection in vivo, IL-6 mRNA is

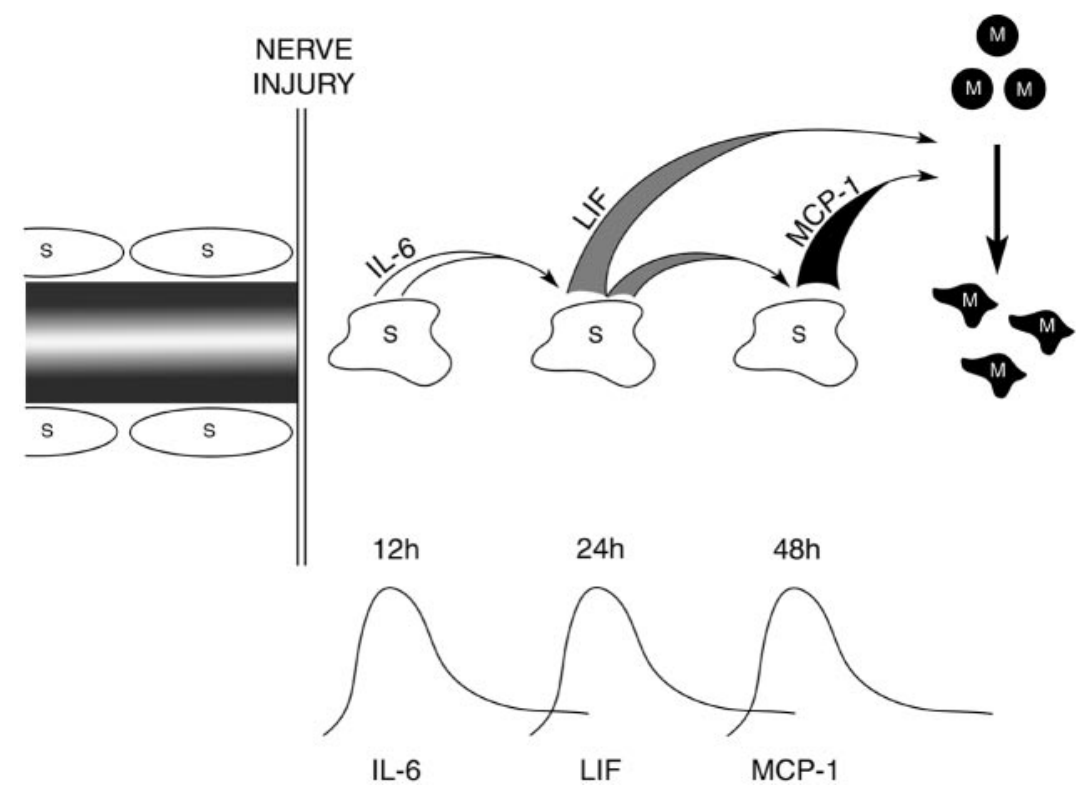

Figure 7. A tentative model of a cytokine-signaling cascade controlling macrophage $(M)$ entry to damaged nerves. An autocrine cascade of IL-6 and LIF enhances Schwann cell $(S)$ secretion of LIF and MCP-1, both of which directly attract macrophages. This indirect regulation of the major macrophage attractant MCP-1 is in agreement with observed delay in macrophage recruitment to transected nerves in vivo. 
strongly but transiently induced, reaching peak levels at $12 \mathrm{hr}$ (Bolin et al., 1995; Bourde et al., 1996; Kurek et al., 1996); LIF mRNA expression peaks at $24 \mathrm{hr}$ and declines at $3 \mathrm{~d}$ postoperatively (Banner and Patterson, 1994; Curtis et al., 1994; Kurek et al., 1996), whereas MCP-1 mRNA reaches peak levels at $48 \mathrm{hr}$ after axotomy (Chien et al., 1997; Toews et al., 1998). These observations, together with our present findings, allow us to propose that in vivo, early induced cytokines such as IL-6 and weaker chemoattractants such as LIF may be essential Schwann cell-derived autocrine factors for the expression of stronger downstream chemotactic signals such as MCP-1 (Fig. 7). In support of this, axonal breakdown appears to be an important regulator of IL- 6 but not MCP-1 production by Schwann cells (Rutkowski et al., 1999). It is also of interest that although there is a very significant deficit in chemotactic activity in the conditioned medium from both lif $-/-$ and $i l-6-/-$ nerves, the activity did not drop significantly further in conditioned medium from double knock-out nerves. A related observation was that in response to cortical injury, the astroglial and microglial responses to injury are significantly reduced in the lif $-/-$ and $i l-6-/-$ mice, but the double knock-out mice show no further reduction in these responses (Sugiura et al., 2000). Therefore, in both the CNS and the PNS, these two cytokines seem to operate in series rather than in parallel, forming one injury response pathway. Supporting the notion of a single pathway is a recent finding that LIF regulates IL-6 expression in the complete Freud's adjuvant model of neurogenic cutaneous inflammation (Zhu et al., 2001). The reverse appears to be true in the sciatic nerve, because IL-6 induces LIF mRNA in Schwann cells and after nerve cut IL- 6 is induced before LIF (Kurek et al., 1996; Toews et al., 1998). The model proposed here is also consistent with the observation that after peripheral nerve damage, the major influx of macrophages begins 2-3 d after injury (Ramon y Cajal, 1928; Beuche and Friede, 1984; Crang and Blakemore, 1986; Perry et al., 1987; Clemence et al., 1989; Stoll et al., 1989). The high potency of MCP-1 and the good correlation of its time course of induction with peak macrophage recruitment suggest that the proposed cascade model may represent an important window into the inflammatory response.

Although MCP-1 and LIF account very well for the chemotactic activity in Schwann cell-conditioned medium in vivo, other chemotactic factors or mechanisms are likely to contribute. For example, cultured Schwann cells produce IL-1 $\beta$ (Bergsteinsdottir et al., 1991). This cytokine induces both LIF and MCP-1 mRNA synthesis under some conditions, although it does not induce MCP-1 in cultured Schwann cells (Carlson et al., 1996; Schwarz et al., 1997; Subang and Richardson, 2001). TNF- $\alpha$, which is expressed by Schwann cells $7 \mathrm{~d}$ after injury (Wagner and Myers, 1996), induces MCP-1 mRNA when added to Schwann cells, and although TNF- $\alpha$ receptor-null mice do not show lower MCP-1 mRNA levels than wild-type mice in the distal stump at early time points, they do at $4 \mathrm{~d}$ after transection (Subang and Richardson, 2001). In some systems, IL-6 acts in concert with its soluble receptor to promote leukocyte recruitment and could function similarly in nerves (Hurst et al., 2001; Marin et al., 2001).

The present observations point to Schwann cells as an important target for therapeutic intervention in peripheral nerve disease. For example, in experimental allergic neuritis, an animal model for human demyelinating polyneuritis (Guillain Barre syndrome), upregulation of MCP-1 mRNA precedes the clinical onset of disease (Fujioka et al., 1999). It remains unclear what first triggers the upregulation of MCP-1 before overt mononuclear cell infiltration. If this situation parallels that of nerve injury described here, activation of autocrine IL-6/LIF circuits in Schwann cells by myelin breakdown, in turn promoted by early recruitment of neuritogenic $\mathrm{T}$ cells, could be the mechanism that stimulates MCP-1 production.

Previous studies have led to the suggestion that a disturbance in the axon-myelin-Schwann cell unit is sufficient to induce macrophage recruitment, and it is widely accepted that this is the initiating signal for the inflammatory reaction in peripheral nerve injury. Axonal breakdown is undoubtedly a key event in Wallerian degeneration, and neuron-derived diffusible molecules may regulate Schwann cell gene expression (Bruck et al., 1995, 1997). Our findings raise the possibility that Schwann cells are also active regulators of the early inflammatory response, rather than simply passive targets of extrinsic signals. This active regulation could be achieved in part by autocrine circuits, which enhance the selectivity and potency of the chemotactic activity appropriately throughout the injury response. It has been shown previously that Schwann cells can establish autocrine circuits mediated by insulin-like growth factor, NT-3, and platelet-derived growth factor-BB, which are sufficient to prevent Schwann cell death in the absence of axons (Jessen and Mirsky, 1999; Meier et al., 1999), and that LIF, in combination with other factors, is an autocrine survival factor for Schwann cells (Dowsing et al., 1999). Furthermore, axonal contact suppresses LIF mRNA expression in Schwann cells (Matsuoka et al., 1997). The latter could represent a physiological mechanism by which regenerating axons restrict the action of such autocrine circuits during repair. Together with our present data, these findings suggest that expression of autocrine loops might be a major mechanism by which Schwann cells regulate gene expression and possibly phenotypic changes when they are deprived of axonal contact.

\section{REFERENCES}

Baggiolini M (1998) Chemokines and leukocyte traffic. Nature 392:565-568.

Banner LR, Patterson PH (1994) Major changes in the expression of the mRNAs for CDF/LIF and its receptor after injury to adult peripheral nerves and ganglia. Proc Natl Acad Sci USA 91:7109-7113.

Bergsteinsdottir K, Kingston A, Mirsky R, Jessen KR (1991) Rat Schwann cells produce IL-1. J Neuroimmunol 34:15-23.

Beuche W, Friede RL (1984) The role of non-resident cells in Wallerian degeneration. J Neurocytol 13:767-796.

Bignold J (1988) Measurement of chemotaxis of polymorphonuclear leukocytes in vitro. J Immunol Methods 108:1-18.

Blanchard AD, Sinanan A, Parmantier E, Zwart R, Broos L, Meijer D, Meier C, Jessen KR, Mirsky R (1996) Oct-6 (SCIP/Tst-1) is expressed in Schwann cell precursors, embryonic Schwann cells and postnatal myelinating Schwann cells: comparison with Oct-1, Krox-20 and Pax-3. J Neurosci Res 46:630-640.

Bolin LM, Verity AN, Silver JE, Shooter EM, Abrams JS (1995) IL-6 production by Schwann cells and induction in sciatic nerve injury. J Neurochem 64:850-858.

Bonmann E, Suschek C, Spranger M, Kolb-Bachofen V (1997) The dominant role of exogenous or endogenous interleukin-1 beta on expression and activity of inducible nitric oxide synthase in rat microvascular brain endothelial cells. Neurosci Lett 230:109-112.

Bourde O, Kiefer R, Toyka KV, Hartung HP (1996) Quantification of IL-6 mRNA in Wallerian degeneration by competitive RT-PCR. J Neuroimmunol 69:135-140.

Brown J, Chen Q, Hong G (1997) An autocrine system for the C-type natriuretic peptide within rat carotid neointima during arterial repair. Am J Physiol 272:H2919-H2931.

Bruck W (1997) The role of macrophages in Wallerian degeneration. Brain Pathol 7:741-752.

Bruck W, Bruck Y, Maruschak B, Friede RL (1995) Mechanisms of macrophage recruitment in Wallerian degeneration. Acta Neuropathol 89:363-367.

Carlson CD, Bai Y, Jonakait GM, Hart RP (1996) IL-1 beta increases LIF mRNA levels through transient stimulation of transcription rate. Glia 18:141-151.

Carroll SL, Frohnert PW (1998) Expression of JE (monocyte chemoattractant protein-1) is induced by sciatic axotomy in wild type rodents but not in C57BL/Wld(s) mice. J Neuropathol Exp Neurol 57:915-930. 
Chien H, Tani M, Glabinski A, Ransohoff R, Griffin JW (1997) Schwann cells selectively express monocyte chemoattractant protein-1 early during Wallerian degeneration. Peripheral Nerve Society Abstr 3:209.

Clemence A, Mirsky R, Jessen KR (1989) Non-myelin-forming Schwann cells proliferate rapidly during Wallerian degeneration in the rat sciatic nerve. J Neurocytol 18:185-192.

Crang AJ, Blakemore WF (1986) Observations on Wallerian degeneration in explant cultures of cat sciatic nerve. J Neurocytol 15:471-482.

Curtis R, Scherer SS, Somogyi R, Adryan KM, Ip NY, Zhu Y, Lindsay RM, DiStefano PS (1994) Retrograde axonal transport of LIF is increased by peripheral nerve injury: correlation with increased LIF expression in distal nerve. Neuron 12:191-204.

Dowsing BJ, Morrison WA, Nicola NA, Starkey GP, Bucci T, Kilpatrick TJ (1999) LIF is an autocrine survival factor for Schwann cells. J Neurochem 73:96-104.

Falk W, Goodwin RH, Leonard EJ (1980) A 48-well micro chemotaxis assembly for rapid and accurate measurement of leukocyte migration. J Immunol Methods 33:239-247.

Fujioka T, Kolson DL, Rostami AM (1999) Chemokines and peripheral nerve demyelination. J Neurovirol 5:27-31.

Gadient RA, Patterson PH (1999) Leukemia inhibitory factor, interleukin- 6 and other cytokines using the gp130 transducing receptor: roles in inflammation and injury. Stem Cells 17:127-137.

Galimi F, Cottone E, Vigna E, Arena N, Boccaccio C, Giordano S, Naldini L, Comoglio PM (2001) Hepatocyte growth factor is a regulator of monocyte-macrophage function. J Immunol 166:1241-1247.

Glass JD, Brushart TM, George EB, Griffin JW (1993) Prolonged survival of transected nerve fibers in C57BL/Ola mice is an intrinsic characteristic of the axon. J Neurocytol 22:311-321.

Gold R, Zielasek J, Kiefer R, Toyka KV, Hartung HP (1996) Secretion of nitrite by Schwann cells and its effect on T-cell activation in vitro. Cell Immunol 168:69-77.

Hartner A, Goppelt-Struebe M, Hocke GM, Sterzel RB (1997) Differential regulation of chemokines by leukemia inhibitory factor, interleukin-6 and oncostatin M. Kidney Int 51:1754-1760.

Harvath L, Falk W, Leonard EJ (1980) Rapid quantification of neutrophil chemotaxis: use of a polyvinylpyrrolidone-free polycarbonate membrane in a multiwell assembly. J Immunol Methods 37:39-45.

Hill MA (1987) The growth of motorneurons and their neurites in relation to Schwann cells harvested from sciatic nerve. Brain Res 430:243-253.

Hurst SM, Wilkinson TS, McLoughlin RM, Jones S, Horiuchi S, Yamamoto N, Rose-John S, Fuller GM, Topley N, Jones SA (2001) I1-6 and its soluble receptor orchestrate a temporal switch in the pattern of leukocyte recruitment seen during acute inflammation. Immunity 14:705-714.

Jessen KR, Mirsky R (1999) Schwann cells and their precursors emerge as major regulators of nerve development. Trends Neurosci 22:402-410.

Jessen KR, Morgan L, Stewart HJS, Mirsky R (1990) Three markers of adult non-myelin-forming Schwann cells, 217c (Ran-1), A5E-3 and GFAP: development and regulation by neuron-Schwann cell interactions. Development 109:91-103.

Jessen KR, Brennan A, Morgan L, Mirsky R, Kent A, Hashimoto Y, Gavrilovic J (1994) The Schwann cell precursor and its fate: a study of cell death and differentiation during gliogenesis in rat embryonic nerves. Neuron 12:509-527.

Klein MA, Moller JC, Jones LL, Bluethmann H, Kreutzberg GW, Raivich G (1997) Impaired neuroglial activation in interleukin-6 deficient mice. Glia 19:227-233.

Kopf M, Baumann H, Freer G, Freudenberg M, Lamers M, Kishimoto T, Zinkernagel R, Bluethmann H, Kohler G (1994) Impaired immune and acute-phase responses in interleukin-6-deficient mice. Nature 368:339-342.

Kurek JB, Austin L, Cheema SS, Bartlett PF, Murphy M (1996) Upregulation of LIF and IL-6 in transected sciatic nerve and muscle following denervation. Neuromuscul Disord 6:105-114.

Lee M-J, Brennan A, Blanchard A, Zoidl G, Dong Z, Tabernero A, Zoidl C, Dent MAR, Jessen KR, Mirsky R (1997) P0 is constitutively expressed in the rat neural crest and embryonic nerves and is negatively and positively regulated by axons to generate non-myelin-forming and myelin-forming Schwann cells, respectively. Mol Cell Neurosci 8:336-350

Longo FM, Manthorpe M, Varon S (1982) Spinal cord neurotrophic factors (SCNTFs): I. Bioassay of Schwannoma and other conditioned media. Brain Res 255:277-294

Lunn ER, Perry VH, Brown MC, Rosen H, Gordon S (1989) Absence of Wallerian degeneration does not hinder regeneration in peripheral nerve. Eur J Neurosci 1:27-33.

Mack TG, Reiner M, Beirowski B, Mi W, Emanuelli M, Wagner D, Thomson D, Gillingwater T, Court F, Conforti L, Fernando FS, Tarlton A, Andressen C, Addicks K, Magni G, Ribchester RR, Perry VH, Coleman MP (2001) Wallerian degeneration of injured axons and synapses is delayed by a Ube $4 \mathrm{~b} / \mathrm{Nmnat}$ chimeric gene. Nat Neurosci 4:1199-1206
Marin V, Montero-Julian FA, Gres S, Boulay V, Bongrand P, Farnarier C, Kaplanski G (2001) The IL-6 soluble IL-6 R alpha autocrine loop of endothelial activation as an intermediate between acute and chronic inflammation: an experimental model involving thrombin. J Immunol 167:3435-3442.

Matsuoka T, Nakane A, Kurihara K (1997) Induction of LIF mRNA by TGF-beta1 in Schwann cells. Brain Res 776:170-180.

Meier C, Parmantier E, Brennan A, Mirsky R, Jessen KR (1999) Developing Schwann cells acquire the ability to survive without axons by establishing an autocrine circuit involving IGF, NT-3, and PDGF-BB. J Neurosci 19:3847-3859.

Mirsky R, Jessen KR (1990) Schwann cell development and the regulation of myelination. Semin Neurosci 2:423-436.

Murphy PM (1994) The molecular biology of leukocyte chemoattractant receptors. Annu Rev Immunol 12:593-633.

Patterson PH (1994) Leukemia inhibitory factor, a cytokine at the interface between neurobiology and immunology. Proc Natl Acad Sci USA 91:7833-7835.

Patterson PH, Fann M-J (1992) Further studies of the distribution of CDF/LIF mRNA. Ciba Found Symp 167:125-140.

Perry VH, Brown MC (1992) Role of macrophages in peripheral nerve degeneration and repair. BioEssays 14:401-406.

Perry VH, Brown MC, Gordon S (1987) The macrophage response to central and peripheral nerve injury: a possible role for macrophages in regeneration. J Exp Med 165:1218-1223.

Perry VH, Brown MC, Lunn ER, Tree P, Gordon S (1990) Evidence that very slow Wallerian degeneration in C57BL/Ola mice is an intrinsic property of the peripheral nerve. Eur J Neurosci 2:802-808.

Ramon y Cajal S (1928) Degeneration and regeneration of the nervous system (May RM, translator). Oxford, UK: Oxford UP.

Rutkowski JL, Tuite GF, Lincoln PM, Boyer PJ, Tennekoon GI, Kunkel SL (1999) Signals for proinflammatory cytokine secretion by human Schwann cells. J Neuroimmunol 101:47-60.

Scheidt P, Friede RL (1987) Myelin phagocytosis in Wallerian degeneration. Properties of millipore diffusion chambers and immunohistochemical identification of cell populations. Acta Neuropathol 75:77-84.

Scherer SS, Salzer JL (2001) Axon-Schwann cell interactions during peripheral nerve degeneration and regeneration. In: Glial cell development, Ed 2 (Jessen KR, Richardson WD, eds), pp 299-330. Oxford, UK: Oxford UP.

Schwarz M, Radeke HH, Resch K, Uciechowski P (1997) Lymphocytederived cytokines induce sequential expression of monocyte and $\mathrm{T}$ cell specific chemokines in human mesangial cells. Kidney Int 52:1521-1531.

Shimon I, Yan X, Ray DW, Melmed S (1997) Cytokine-dependent gp130 receptor subunit regulates fetal pituitary adrenocorticotrophin hormone and growth hormone secretion. J Clin Invest 100:357-363.

Siebert H, Sachse A, Kuziel WA, Maeda N, Bruck W (2000) The chemokine receptor CCR2 is involved in macrophage recruitment to the injured peripheral nervous system. J Neuroimmunol 110:177-185.

Stewart CL, Kaspar P, Brunet LJ, Bhatt H, Gadi I, Kontgen F, Abbondanzo SJ (1992) Blastocyst implantation depends on maternal expression of leukaemia inhibitory factor. Nature 359:76-79.

Stoll G, Griffin JW, Li CY, Trapp BD (1989) Wallerian degeneration in the peripheral nervous system: participation of both Schwann cells and macrophages in myelin degradation. J Neurocytol 18:671-683.

Subang MC, Richardson PM (2001) Influence of injury and cytokines on synthesis of monocyte chemoattractant protein-1 mRNA in peripheral nervous tissue. Eur J Neurosci 13:521-528.

Sugiura S, Lahav R, Han J, Kou S-Y, Banner LR, de Pablo F, Patterson PH (2000) Leukemia inhibitory factor is required for normal inflammatory responses to injury in the peripheral and central nervous systems in vivo and is chemotactic for macrophages in vitro. Eur J Neurosci 12:457-466.

Sun D, Hu X, Liu X, Whitaker JN, Walker WS (1997) Expression of chemokine genes in rat glial cells: the effect of myelin basic proteinreactive encephalitogenic T cells. J Neurosci Res 48:192-200.

Toews AD, Barrett C, Morell P (1998) MCP-1 is responsible for macrophage recruitment following injury to sciatic nerve. J Neurosci Res 53:260-267.

Varon S, Skaper SD, Manthorpe M (1981) Trophic activities for dorsal root and sympathetic ganglionic neurons in media conditioned by Schwann and other peripheral cells. Brain Res 227:73-87.

Villiger PM, Terkeltaub R, Lotz M (1992) Monocyte chemoattractant protein-1 expression in human articular cartilage. Induction by peptide regulatory factors and differential effects of dexamethasone and retinoic acid. J Clin Invest 90:488-496.

Wagner R, Myers RR (1996) Schwann cells produce TNF-alpha: expression in injured and non-injured nerves. Neuroscience 73:625-629.

Wilkinson PC (1982) Chemotaxis and inflammation, Ed 2. Amsterdam: Elsevier Science.

Zhu M, Oishi K, Lee SC, Patterson PH (2001) Studies using leukemia inhibitory factor (LIF) knock-out mice and a LIF adenoviral vector demonstrate a key anti-inflammatory role for this cytokine in cutaneous inflammation. J Immunol 166:2049-2054. 